\title{
単一および多段フラットスプレーノズルによる 高温鉛直面の冷却特性
}

\author{
播木 道春 ${ }^{*} \cdot$ 大西 晶*・森田 昌孝 $* 2$
}

Heat Transfer Characteristics with Single and Multi-stage Flat Spray Nozzles on a Hot Vertical Surface Cooling Michiharu Hariki, Akira Onishi and Masataka Morita

Synopsis : In order to improve water cooling technique for flanges in rolled $\mathrm{H}$-shapes for the prevention of cooling buckling on thin web, an experimental study on a hot vertical surface cooling with single and multi-stage spray nozzles was carried out.

First, the effects of nozzle pressure, nozzle angle and nozzle-plate distance on heat transfer coefficient of a hot vertical surface were investigated with a single spray nozzle. Next, with multi-stage spray nozzles the effect of flowing water from the upper area on heat transfer coefficients of the lower water strike zone and flowing water zone was investigated.

The results obtained are summarized as follows.

(1) The heat transfer coefficient of water strike zone with a single spray nozzle was described by water flux which is functions of nozzle pressure, nozzle angle and nozzle-plate distance.

(2) In the case of high temperature with a single spray nozzle, the heat transfer coefficient ratio between flowing water zone and water strike zone is not affected by the cooling conditions, such as nozzle pressure, nozzle angle and nozzle -plate distance.

( 3 ) However, in the case of low temperature, the ratio between flowing water zone and water strike zone on heat transfer coefficient strongly depends on the nozzle operating conditions.

(4) On the other hand, in the case of multi-stage spray cooling, the existance of flowing water from the upper area enhances heat transfer coefficient of lower flowing zone. The maximum ratio of heat transfer coefficient between flowing water zone with water flowing down from above and without is from about 1.3 to 1.7 .

Key words : water cooling; H-shapes ; spray nozzle ; hot vertical surface; heat transfer coefficient.

\section{1. 緒言}

H形鋼は厚肉のフランジ部と薄肉のウェブ部から成る形状 の特殊性によって, 熱間圧延後の放冷過程でウェブ座屈を 起こしやすいり。そのため, 压延加工中, または圧延終了後 にフランジ部を強制的にスプレー冷却することにより，薄 肉ウェブを有するH形鋼の製造が開始された2)。

ところで，スプレーノズルによってフランジ部を冷却す るに際しては，ノズルから噴霧された液滴が直接フランジ 部表面に当たる衝突域の泠却能力だけでなく, 衝突後に表 面に沿って流れる流水方向の冷却能力を精度良く把握して おく必要がある。前者の冷却能力, 寸なわち, 衝突域の熱 伝達率はH本鉄鋼協会が中心となってまとめられている3 ${ }^{3,4)}$ 。 一方, 後者の熱伝達率については, 今村らが移動冷却実験 によって, 衝突域近傍の熱伝達率と衝突域の熱伝達率に及
ぼす流下水の影響を明らかにしている5,6)。しかしながら， 今村らは, フラットノズルとスポットノズルの組み合わせ で調查しており，汎用的な条件での冷却特性については， 十分な解明がなされていない。

そこで，高温鉛直面をスプレー冷却する場合の基本的な 伝熱現象を明らかにしておく必要があると考え, 本研究で は，まず単一フラットスプレーノズルを用いた場合につい て, 鉛直面衝突域とその後の表面に沿って流れる流水力向 の熱伝達率に及ぼすノズル圧力, ノズル角度および噴霧距 離の影響を明らかにした。つぎに，鉛直方向に多段にフラ ットスプレーノズルを配置した場合について，鉛直面衝突 域と流水域の熱伝達率を調查し, 単一ノズルとの比較を行 うととに，上部からの流下水の影響を明らかにしたので 報告する。

平成 8 年11月8 日受付 平成 9 年 1 月14日受理（Received on Nov. 8, 1996 ; Accepted on Jan. 14, 1997)

* 住友金属I. 棠(株)総命技術研究所 (Corporate Research \& Development Laboratories, Sumitomo Metal Industries, Ltd., 16 Sunayama Hasakimachi Kashima-gun Ibaraki-ken 314-02)

* 2 住金マネジメント(株)鹿岛事業部（Kashima Division, Sumikin Management Co., Ltd.) 


\section{2. 実験方法}

\section{$2 \cdot 1$ 単一スプレー実験}

高温鉛直面に衝突したスプレー冷却水の衝突域から流水 方向にかけての熱伝達率を测定寸るために用いた実験方法

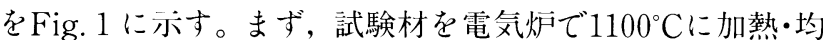
熱後，裹面を溶着熱電対で測温しながら，片面を水冷した。 武験材は，表面酸化スケールの影響を除くために，酸化さ れにくいステンレス材 (SUS310S) を選択し, 板幅 $300 \mathrm{~mm}$, 厚及 $3 \mathrm{~mm}$ の寸法のものを用いた。流水方向の測温位置は， ノズルから噴霧された冷却水が試験材と衝突する位置を基 準に，上方向(一方向）には $10 \mathrm{~mm}$ ，下方向(十方向)には 10 ， $30,50,100 \mathrm{~mm}$ とした。流水方向の熱伝達率に及ぼす諸因 子としては, Table 1 に示すように供試ノズル圧力 $\mathrm{P} は 0.02$ から0.1MPa，ノズル先端から試験材までの水平距離として の噴霧距離1は50から $250 \mathrm{~mm}$, 水平面からの伏せ角としての ノズル角度 $\theta$ は $0^{\circ}$ から $25^{\circ}$ としたなお供試ノズルは, 圧力 $0.3 \mathrm{MPa}$ で噴霧角度 $80^{\circ}$, 水量 $401 / \mathrm{min}$ 仕様の市販フラット ノズルを用いた。

\section{$2 \cdot 2$ 多段スプレー実験}

高さ力向多段にスプレーノズルを配置した場合の熱伝達 摔を測定するにあたり，適正なノズル条件を設定するため に，まずノズルから噴霧された冷却水の鉛直面上における 流動挙動を調査した。実験方法はFig. 2 に示すように, 各段 ノズルの設置角度 (水平面からの伏せ角度 $\theta=10^{\circ}$ から $25^{\circ}$, ,

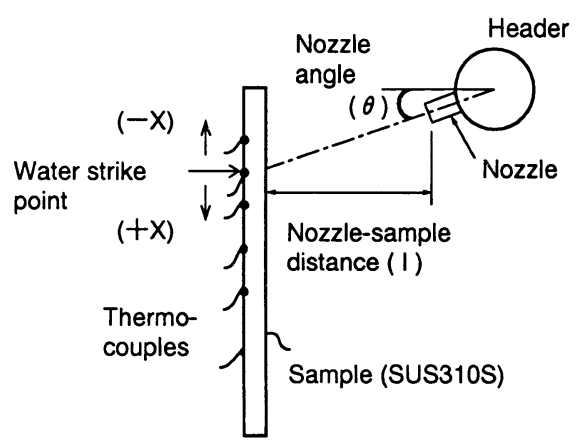

Fig. 1. Temperature measuring method.

Table 1. Experimental conditions of single spray cooling.

\begin{tabular}{|c|c|c|}
\hline \multicolumn{2}{|c|}{ Nozzle pressure $(P)$} & $0.02 \sim 0.1 \mathrm{MPa}$ \\
\hline \multicolumn{2}{|c|}{ Nozzle-sample distance (I) } & $50,150,250 \mathrm{~mm}$ \\
\hline \multicolumn{2}{|c|}{ Nozzle angle $(\theta)$} & $0.10 .25^{\circ}$ \\
\hline \multicolumn{2}{|c|}{$\begin{array}{l}\text { Distance from water strike } \\
\text { point }(X)\end{array}$} & $\begin{array}{l}0, \pm 10,30,50 \\
100 \mathrm{~mm}\end{array}$ \\
\hline S ample & $\begin{array}{l}\text { Size } \\
\text { Material } \\
\text { Surface roughness } \\
\text { Scale thickness }\end{array}$ & 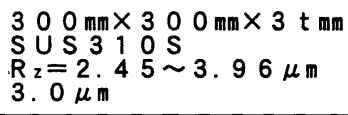 \\
\hline \multicolumn{2}{|c|}{ Sample temp. } & $1100^{\circ} \mathrm{C}$ \\
\hline \multicolumn{2}{|c|}{ Water temp. } & $23 \sim 26^{\circ} \mathrm{C}$ \\
\hline
\end{tabular}

ズル軸周方向の捻れ角度 $\beta=5^{\circ}$ から $20^{\circ}$ )およ゙゙ノズル压力 $(\mathrm{P}=0.02$ から 0.1MPa $)$ をパラメータとして, 透明なアクリ ル板 (高さ $250 \mathrm{~mm} \times$ 幅 $800 \mathrm{~mm} \times$ 厚さ $10 \mathrm{~mm}$ ) を用いて, 片側 に冷却水を衝突させ反対側から観察を行った。冬段ノズル の幾何学的条件はFig. 2 に示寸通りで, 紙而に鉛消な幅方向

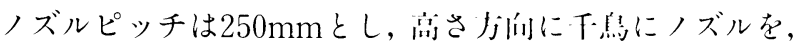
上中段は 3 個，下段は 4 個配置した。なお，供武ノズルの 上段は压力 $0.3 \mathrm{MPa}$ で噴霧角度 $40^{\circ}$ ，水早 $241 / \mathrm{min}$ の斜方つ ラットノズル, 中下段は前項の単一ノズル試馻と同じ仕様 のノズルを用いた。

つぎに，多段ノズルを用いた場合の品温鈆淔面における 各段ノズルの冷却水衝突域と流水域の熱伀達率を測定する ために，単一ノズル実騒と同じ方法で測温实騒を行った。 その実験条件をTable 2 に亦す。ノズル設算们度は, 冷間実 験より，各段ノズルの衝突域が槀さう们に連続している条 件を適正值として選択し，上部からの流卜水の影響につい ては，高さ方向のノズル压力の組み合わせを変えて調查し た。また，測温位置については，冬段ノズルの离さ力们中 央部で代表した。

\section{3. 実験結果および考察}

\section{$3 \cdot 1$ 単一スプレー時の冷却曲線}

Fig. 3 はノズルから噴霧された冷却水と試験材の衝突域に て得られた泠却曲線の代表例である。ノズル伏せ角度 $\theta$ は 10 ， ノズル圧力Pは0.05MPaの場合において，噴霧距離1をパラ メータとしている。噴霧距離1が50 $\mathrm{mm}$ では，衝突中心部と 高さ方向上下 $10 \mathrm{~mm}$ 離れた位置での冷却パターンの差は小さ く，150mm以上離れると衝突中心より 1 $10 \mathrm{~mm}$ の位置の冷

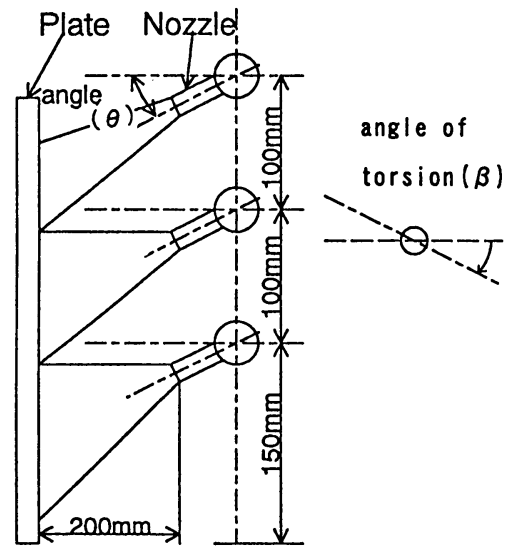

Fig. 2. Arrangement of multi-stage spray nozzles.

Table 2. Experimental conditions of multi-stage spray cooling.

\begin{tabular}{l|l}
\hline Nozzle angle $(\theta)$ & upper: $22^{\circ}$, middle $: 20^{\circ}$, lower $: 13^{\circ}$ \\
\hline Nozzle angle $(\beta)$ & upper $: 11^{\circ}$, middle $: 5^{\circ}$, lower $: 16^{\circ}$ \\
\hline
\end{tabular}



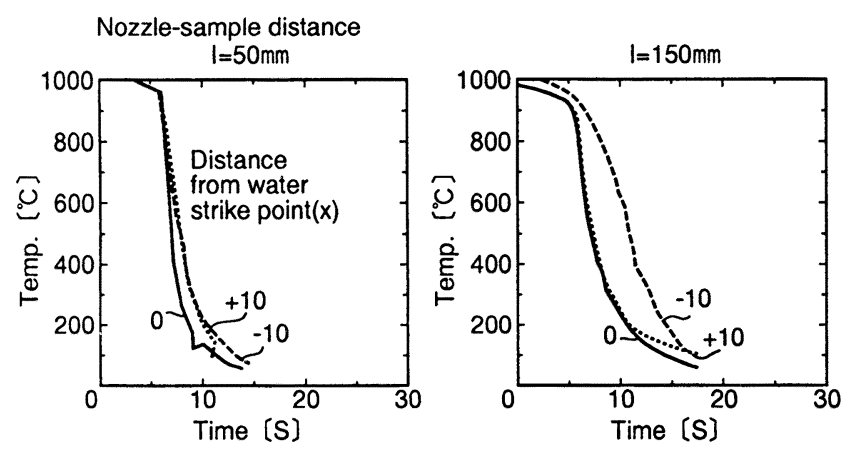

Fig. 3. Cooling curves on water strike zone of samples by a single nozzle.

(Nozzle angle : $10^{\circ}$, pressure : $0.05 \mathrm{MPa}$ )
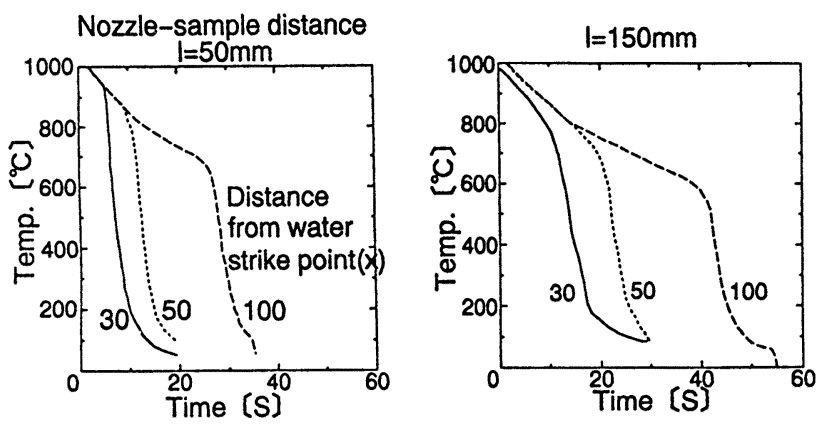

Fig. 4. Cooling curves on flowing water zone of samples by a single nozzle.

(Nozzle angle : $10^{\circ}$, pressure : $0.05 \mathrm{MPa}$ )

\section{却が遅れる倾问が见られた。}

Fig. 4 は流水域における泠却曲線の代表例であり, 条件は Fig. 3 と闹じで衝突位置より流水方向に $30 \mathrm{~mm}, 50 \mathrm{~mm}$, $100 \mathrm{~mm}$ 離れた位置での挙動を示す。各位置での冷却パター

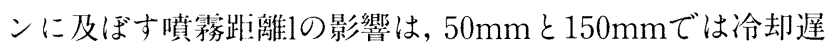
れの明確な善が垫められるが，150mm以上では小さい。ま た, 衝突位置から $30 \mathrm{~mm}$ と 50mmの位置では冷却開始から急 激な温度变化が見られるが，100mmの位置では裏面温度が $600^{\circ} \mathrm{C}$ まで比較的ゆるやかに变化している。

\section{$3 \cdot 2$ 単一スプレー時の冷却特性}

Fig. 5 は測温值の一次元伝熱逆計算法》にてて得られた泠却 水衝突域から流水域にかけての熱伝達率と表面温度との関 係を示す。笑験条作は，ノズル伏せ角度 $\theta$ は $10^{\circ}$, 噴霧距離1 は150mm, ノズル1: 的は0.05MPaである。流水域では, 表面温度が $800^{\circ} \mathrm{C}$ から $700^{\circ} \mathrm{C}$ あたりで，熱伝達率の急激な上昇 が見られることから，蒸気膜の崩壊が生じていることがわ かるが, 衝突域では胃られない。流水域の熱伝達率は, 衝 突域に比して槀温域では，1000 W/ $\mathrm{m}^{2} \mathrm{~K}$ 以下と小さい。一 方，表面温度が低温になるにつれて，その值は急激に大き くなる傾们を活者とも示す。なお，衝突域の熱伝達率とし ては, 衝突域の水量密度との関係で, 衝突中心 $と$ 上下 $10 \mathrm{~mm}$ の算術平均值を用いることにした。

Fig. 6 は, 表而温度 $800^{\circ} \mathrm{C}$ と $400^{\circ} \mathrm{C}$ にいて, 衝突域の熱伝

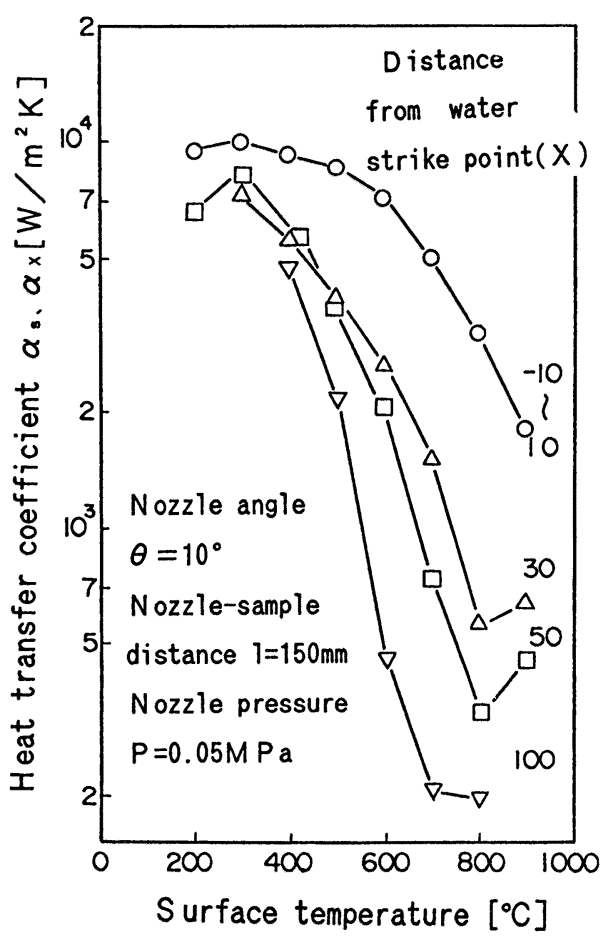

Fig. 5. Relation between surface temperature and heat transfer coefficient through the flowing water zone.

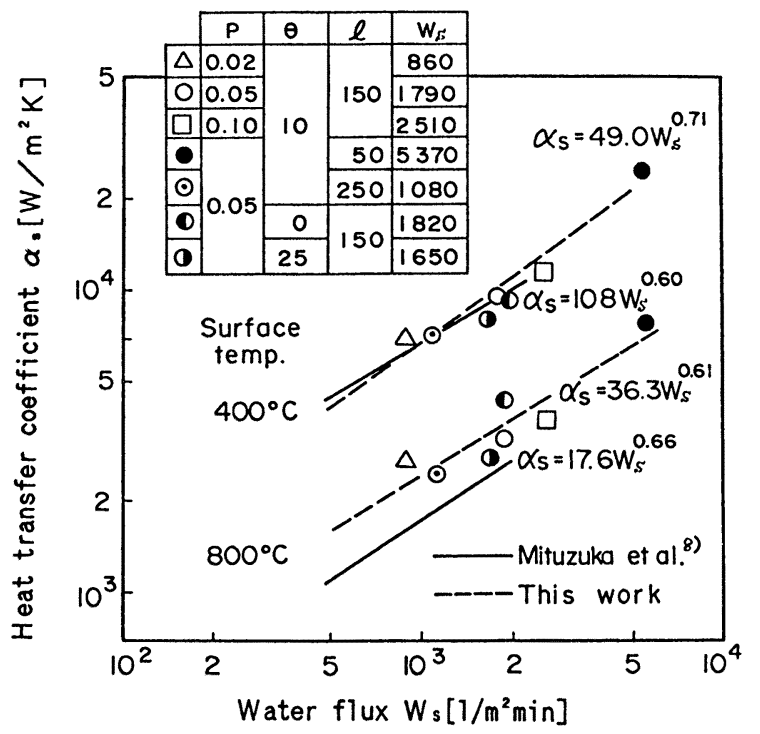

Fig. 6. Relation between water flux and heat transfer coefficient on water strike zone by a single nozzle.

達率 $\alpha_{\mathrm{s}}$ を水量密度 $\mathrm{W}_{\mathrm{s}}$ で整理した結果を示す。なお, 衝突域 の水量密度の算出については, 噴霧有効厚みを $30 \mathrm{~mm}$ 一定と し, 噴霧幅を幾何学的に, ノズル伏せ角度 $\theta$ と噴霧距離 1 から 求めた。これからノズル圧力 $\mathrm{P}$, ノズル伏世角度 $\theta$ 及び噴第 距離1を水量密度 $\mathrm{W}_{\mathrm{s}}$ に置き換えることにより衝突域の熱伝達 率を記述できることがわかった。その值について水平上下 面冷却主体の三塚らの式8) と比べてみると, 低温域では比較 的良く一致しているが，高温域ではやや大きい傾向になっ 


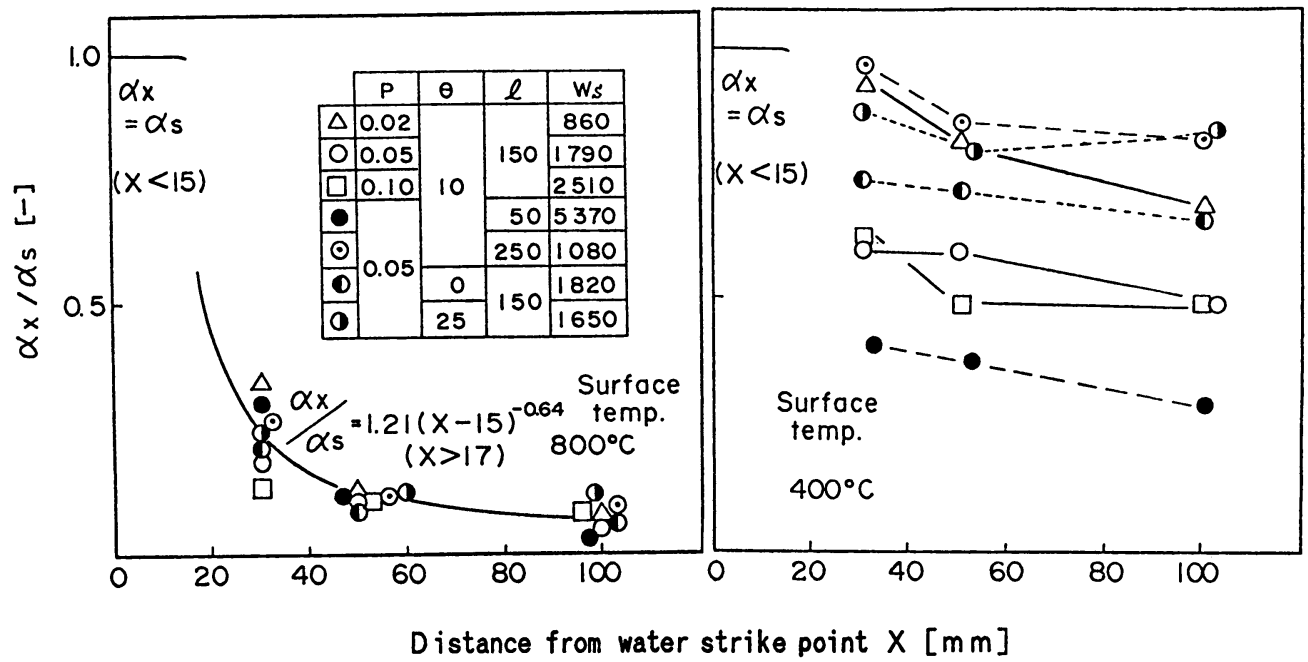

Fig. 7. Effect of distance from water strike point on heat transfer coefficient.

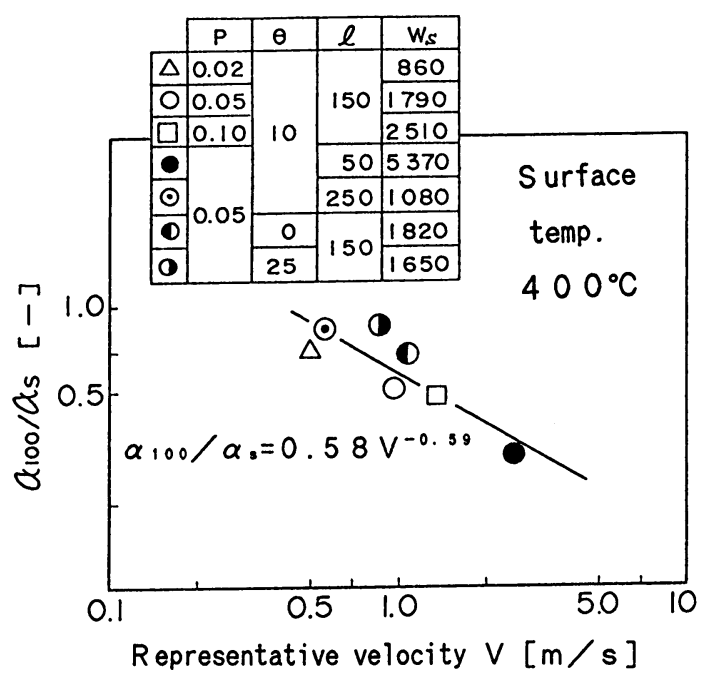

Fig. 8. Relation between representative velocity and heat transfer coefficient ratio $\left(\alpha_{100} / \alpha_{\mathrm{s}}\right)$.

ている。その理由としては，本実験のような低圧力の噴霧 では液滴が十分分散されず，連続流的な噴霧による運動量 の增大効果のためと考えられる。

Fig. 7 は表面温度 $800^{\circ} \mathrm{C}$ と $400^{\circ} \mathrm{C}$ において, 衝突位置から流 水方向にかけての熱伝達率の減衰比率 $\left(\alpha_{\mathrm{x}} / \alpha_{\mathrm{s}}\right)$ を示す。流 水方向の熱伝達率 $\alpha_{\mathrm{x}}$ は, 衝突中心から50mmにかけて大きく 変化する。高温域では, 衝突域の熱伝達率 $\alpha_{\mathrm{s}}$ に対する比率は $10 \%$ まで小さくなりノズル圧力P，ノズル伏せ角度 $\theta$ および 噴霧距離1の影響は小さい。今村らの実験らによると,鋼板表

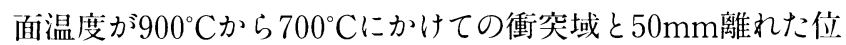
置での熱伝達比率は30\%程度の值が得られており, 今回の 結果とほぼ一致した傾向を示している。一方, 表面温度 $400^{\circ}$ Cでは衝突位置から流水方向にかけての減衰比率 $\left(\alpha_{\mathrm{x}} / \alpha_{\mathrm{s}}\right)$ は，冷却条件によって大きく異なる。すなわち衝笑域にお いて, 冷却水の飛散が少ない条件であるノズル圧力 $\mathrm{P} か ゙$ 低い, ノズル伏せ角度 $\theta$ ガ大きい, または噴霧距離仍長い程, 減衰 比率 $\left(\alpha_{\mathrm{x}} / \alpha_{\mathrm{s}}\right)$ は小さい。

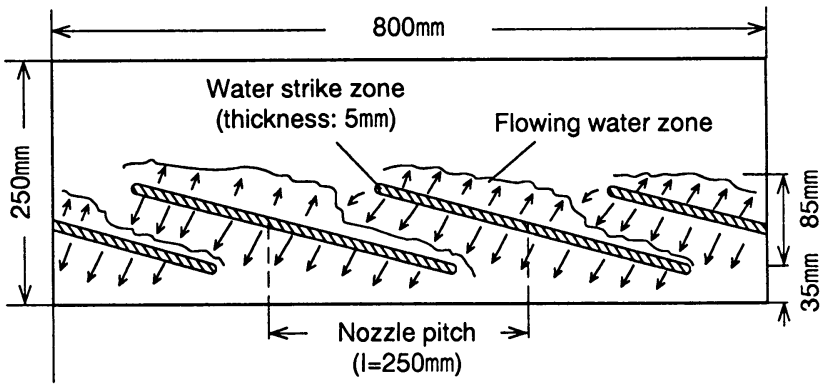

Fig. 9. Water flowing pattern for lower nozzles.

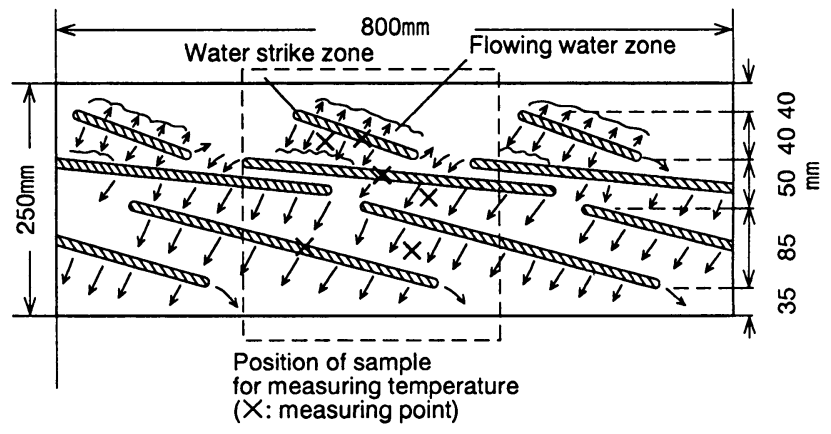

Fig. 10. Water flowing pattern for multi-stage nozzles.

Fig. 8 は, 表面温度 $400^{\circ} \mathrm{C}$ の時に, 衝突位置において国岡 ら9)が提唱した代表速度Vで衝突域から100mmの位置におけ る熱伝達率 $\alpha_{100}$ の減衰比率 $\left(\alpha_{100} / \alpha_{\mathrm{s}}\right)$ を整理した結果を示 寸。

これから，液滴の運動量を連続流体のごとく扱い，衝突 速度 $\mathrm{v}_{\mathrm{s}}$ と水量密度 $\mathrm{W}$ の積の平方根で定義され, 速さの次元を 持つ代表速度 $\mathrm{V} か ら$ 低温域における流水方向の熱伝達率の減 衰比率 $\left(\alpha_{100} / \alpha_{\mathrm{S}}\right)$ を予測できることがわかった。

\section{$3 \cdot 3$ 多段スプレー時の流動挙動}

高さ方向多段に設置されたフラットスプレーノズルから 噴霧された泠却水の流動挙動について，その代表例をFig. 9 およびFig.10に示す。Fig. 9 は下段ノズル単独の場合であり， 
実騃条件は，ノズル压力Pは0.02MPa，ノズル伏せ角度 $\theta=$ $13^{\circ}$ ，ノズル捻れ角度 $\beta=16^{\circ}$ である。冷却表面(この場合は, アクリル板)に形成される衝突域の高さ方向の長さは約 85 $\mathrm{mm}$, 厚みは $5 \mathrm{~mm}$ 程度で, その值はノズル圧力に比例して 変化する。冷却水は衝突後, 高さ方向上向きには $30 \mathrm{~mm} の$ 流 水域か形成され，下向きの流れの半分は隣の上向き流水域 と干涉し, 残りの半分はそのまま下に流れ，最下面 $35 \mathrm{~mm}$ 流水域のみとなる。

Fig.10は 3 段すべてのノズルから冷却水を噴霧した場合で あり，ノズル庄力Pは上下段が $0.05 \mathrm{MPa}$ ，中段は $0.1 \mathrm{MPa}$, ノズル設置角度はTable 2 に示す通りである。冷却水衝突域 での挙動は, 単段ノズルの場合と同じであるが, 流水域で は, 高さ方向上何きの流れは上段以外，す心゙て下向き流れ に変わる。Table 2 で示した設置条件は高さ方向に衝突域が 重なったり，離れたりしない基準より求めた条件であり， 高温鉛直面が紙面の左右方向に移動する際において，多段 ノズルを適用寸る場合の適正ノズル条件の一つと言える。

\section{$3 \cdot 4$ 多段スプレー時の冷却特性}

Fig.11は各段ノズルから噴霧された泠却水の衝突域におけ る水量密度W と熱伝達率 $\alpha_{\mathrm{S}}$ の関係を示す。冷却面温度が 900

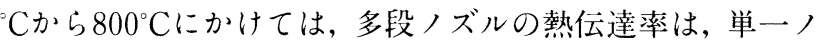
ズルの值と比較的良い対応を示している。一方, $700^{\circ} \mathrm{C}$ か

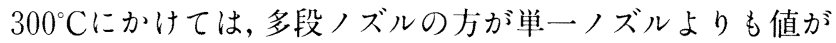
小さい傾向にある。その理由としては，上部ノズルからの 流下水が衝突域に流れ込んでくるため, 液滴の衝突圧が減 衰するとともに，新しい液滴と高温面の接触が時間的，空 間的にも小さくなったためと考えられる。

Fig.12は，上:部から流下水のない場合の水量密度 $W_{\mathrm{f} 0}$ と熱 伝達率 $\alpha_{\mathrm{f} 0}$ の関係をホすすこの場合, 上段ノズルの方が中下 段ノズルに比べて熱伀達率が小さい傾向にある。その理由 としては，ノズルピッチが同じであるにも係わらず，ノズ

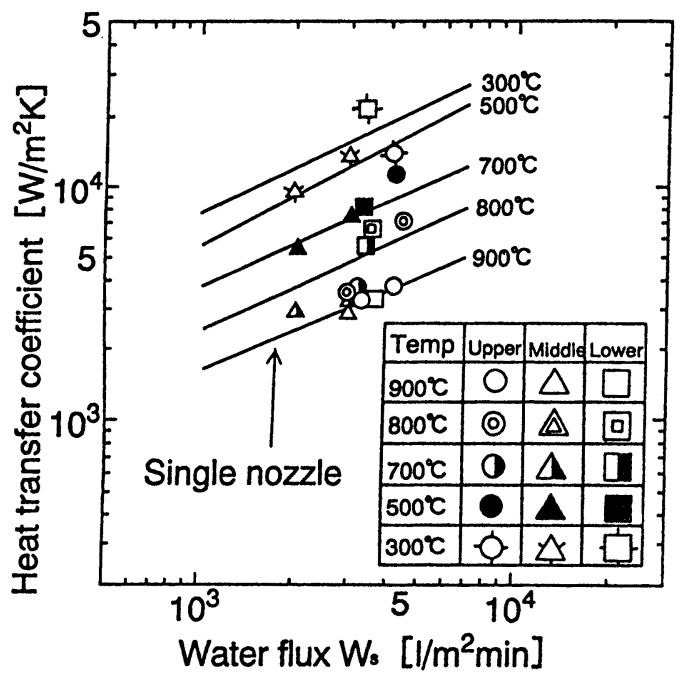

Fig. 11. Relation between water flux and heat transfer coefficient on water strike zone by multi-stage nozzles.
ル噴霧角が半分なために，流水域の形成が中下段に比較し て十分ではないためと考えられる。中下段ノズルの熱伝達 率 $\alpha_{\mathrm{f} 0}$ に及ぼす水量密度 $\mathrm{W}_{\mathrm{f} 0}$ の影響は, 高温域では小さく, 低温域になるにつれて大きくなる傾向を示す。また，㶲中 の破線は, 三塚らの式8)示しており, 今回得られたデータ はその周囲に位置している。このことは，流水域を便宜的 に噴霧域の一部として扱える可能性を示唆している。

Fig.13は上部から流下水がある場合について,その影響を 整理した結果を示す。四中の横軸は，各段ノズルから噴霧 された冷却水に対する上部からの流下水の割合を各段の水 量密度に換算した值であり,ここでは, 流下水量密度比 $\left(\mathrm{W}_{\mathrm{f}} /\right.$ $\mathrm{W}_{\mathrm{f} 0}$ ) と定義する。困中の縦軸は, 上部流下水のない場合の

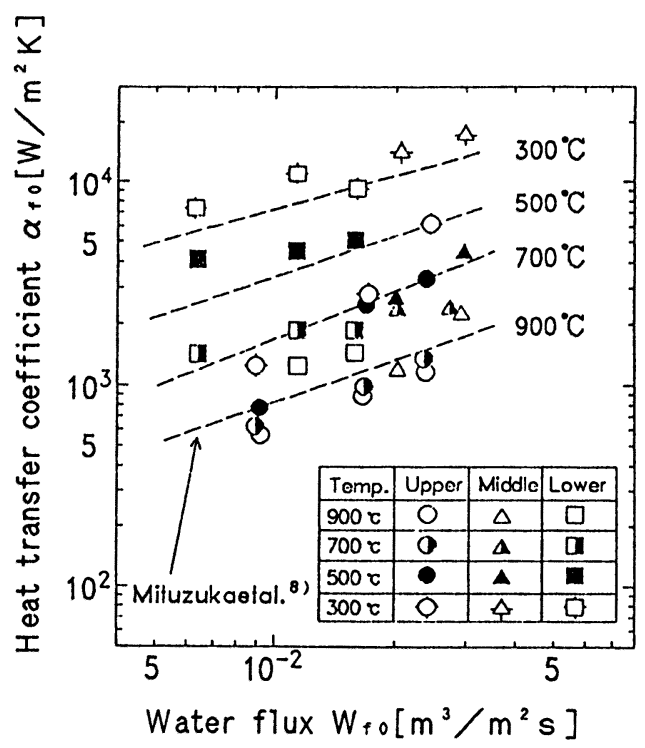

Fig. 12. Relation between water flux and heat transfer coefficient on flowing water zone without flowing water from upper area.

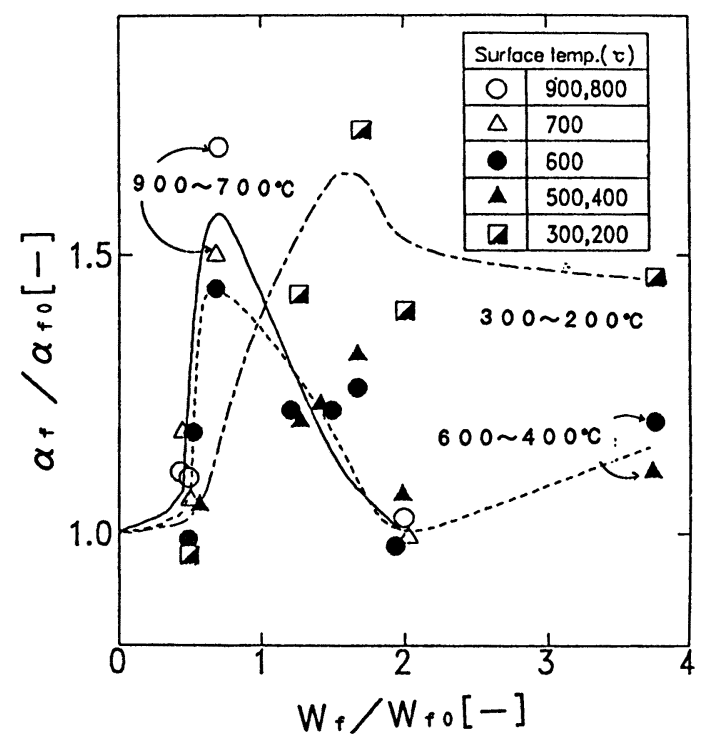

Fig. 13. Relation between water flux ratio $\left(\mathrm{W}_{\mathrm{f}} /\right.$ $\left.\mathrm{W}_{\mathrm{f} 0}\right)$ and heat transfer coefficient ratio $\left(\alpha_{\mathrm{f}} / \alpha_{\mathrm{f} 0}\right)$. 
熱伝達率 $\alpha_{\mathrm{f} 0}$ に対する上部流下水のある場合の熱伝達率比率 $\left(\alpha_{\mathrm{f}} / \alpha_{\mathrm{f} 0}\right)$ である。これから, 流水域の熱伝達率は上部から の流下水により増加し，その挙動は冷却面温度域によって 異なることが明らかになった。すなわち, $900^{\circ} \mathrm{Cから} 400^{\circ} \mathrm{C} の$ 温度域の場合, 流下水量密度比 $\left(\mathrm{W}_{\mathrm{f}} / \mathrm{W}_{\mathrm{f} 0}\right)$ が 1 以下の範囲 では流下水の増加の伴い, 熱伝達率比率 $\left(\alpha_{\mathrm{f}} / \alpha_{\mathrm{f} 0}\right)$ は大きく なる。しかし, 流下水量密度比 $\left(\mathrm{W}_{\mathrm{f}} / \mathrm{W}_{\mathrm{f} 0}\right)$ が 1 以上では, 熱伝達率比率 $\left(\alpha_{\mathrm{f}} / \alpha_{\mathrm{f} 0}\right)$ は減少し, 1.0 に近くなる傾向を示す。 一方, $300^{\circ} \mathrm{C}$ か $5200^{\circ} \mathrm{C}$ の温度域の場合, 流下水量密度比 $\left(\mathrm{W}_{\mathrm{f}} / \mathrm{W}_{\mathrm{f} 0}\right)$ の增加 $と$ とに熱伝達率比率 $\left(\alpha_{\mathrm{f}} / \alpha_{\mathrm{f} 0}\right)$ は大きく なり, 流下水量密度比 $\left(\mathrm{W}_{\mathrm{f}} / \mathrm{W}_{\mathrm{f} 0}\right)$ が 2 を越えると飽和する 傾问を示す。ところで, 各温度域における熱伝達率比率 $\left(\alpha_{\mathrm{f}} /\right.$ $\left.\alpha_{\mathrm{f} 0}\right)$ の最大值は, 流下水量密度比 $\left(\mathrm{W}_{\mathrm{f}} / \mathrm{W}_{\mathrm{f} 0}\right)$ が 2 以下で存在 し, それらの最大值は1.3から1.7の範囲であった。この点 に関しては，今村らの実験6においても，ノズルを多段化し た場合には流下水の影響により，下段ノズル部は低水量の 場合に1.5倍程度の熱伝達率の増加が確認されている。

\section{4. 結言}

高温鉛直面のスプレー冷却実験を行い, 単一フラットス プレーノズルを用いた場合と, 高さ方向多段にフラットス プレーノズルを配置した場合について, 冷却水の鉛直面衝 突域およびその後の表面に沿って流れる流水方向の熱伝達 率に及ぼす諸因子の影響を検討した結果は, つぎの通りで ある。

(1) 単一フラットノズルの場合, 冷却水衝突域の熱伝達 率に及ぼすノズル圧力, ノズル角度および噴霧距離の影響 は，水量密度に置き換えることにより記述できる。

(2)流水方向の熱伝達率は, 衝突中心から50mmにかけて 大きく変化し, 高温域ではノズル圧力, ノズル角度および 噴霧距離の影響は比較的小さい。

( 3 ) 一方, 低温域での流水方向の熱伝達率の減衰比率は 衝突域における冷却条件によって大きく異なり，ノズル圧 力, ノズル角度および噴霧距離を衝突位置での代表速度に
置き換えることにより予測できる。

(4) 多段フラットノズルの場合, 冬段ノズルから噴霧さ れた冷却水は冷却表面衝突後, 最上段のみ上:向きに流れ, あとはすべて下向き流れに変わる。

（5）多段ノズルの熱伝達率は，上部流卜水の影響を受け て, 衝突域では単一ノズルに比べて低く, 流水域で増加し, その挙動は冷却面温度域によって異なる。

（6）すなわち，上部流下水のない場合の熱伀達率 $\alpha_{\mathrm{f} 0}$ に対 する上部流下水のある場合の熱伝達摔比率 $\left(\alpha_{\mathrm{f}} / \alpha_{\mathrm{f} 0}\right)$ の最大 值は, 流下水量密度比 $\left(\mathrm{W}_{\mathrm{f}} / \mathrm{W}_{\mathrm{f} 0}\right)$ が 2 以下で存在し, それ らの最大値は $1.3 か ら 1.7 の$ 範网であった。

\section{記 号}

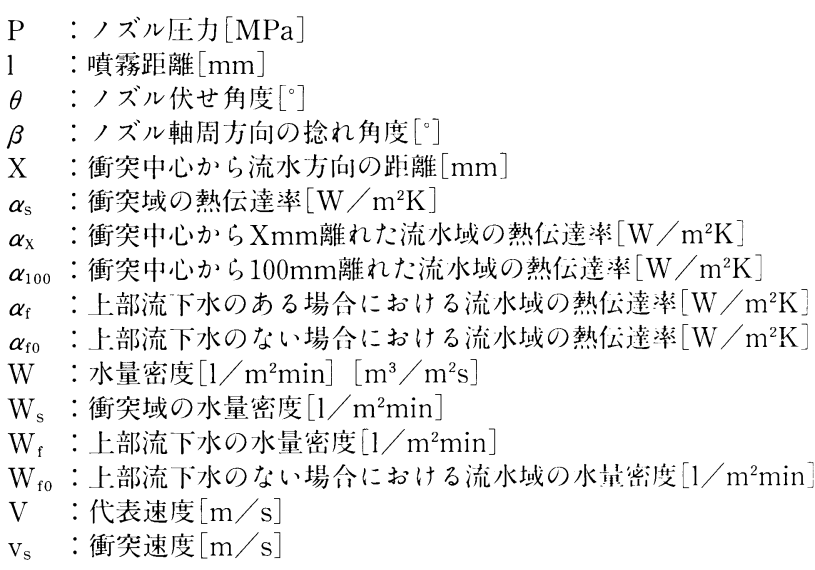

\section{文献}

1) 黒川征男, 藤本 武, 稻堛 彰, 尼野均, 炎泇内醇, 寺前昭, 板橋義則：材料とプロセス, 3 (1990), 497.

2 ) 安河内醇, 長谷川博行, 稻顷 彰, 照川征: 男, 不橋俊弘: 材料 $\varepsilon$ プロセス, 3 (1990), 1343.

3 ）日本鉄鋼協会：鋼材の強制冷却, (1978), 4.

4) 日本鉄鋼協会：鉄鋼轅造プロ七スにおける价却技術，(1988), 59 .

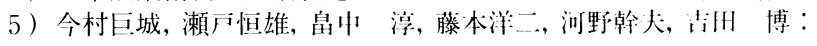
材料とプロセス, 5 (1992), 1578.

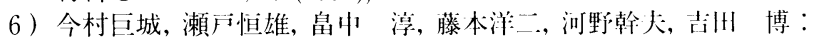
材料とプロセス, 6 (1993), 486.

$7)$ J.V.Beck: Int.J.Heat Mass Transf., 13 (1970), 703.

8 ）日本鉄鋼協会：鋼材の強制冷却，(1978), 16.

9 ) 国岡計夫, 平田賢, 杉川峻一, 神毛宽：11本機械学会論文集, 45-390 (1979), 282 